\title{
環境条件を考慮したポリマーセメント系 断面修復材の性能評価
}

\author{
伊藤 正憲*1 $\cdot$ 魚本 健人*2
}

\begin{abstract}
概要: 劣化したコンクリート構造物の補修対策としてポリマーセメント系断面修復材が使われることが多い。しかし， 予想以上の短い期間で再劣化している事例が後を絶たない。再劣化する原因のひとつとして環境条件を考慮した適切 な材料や工法の選定を行わなかったことが考えられる。そこで本研究では, 今後, 合理的で効果的な断面修復工法の 確立を目指して，実現場を想定した環境条件に試験体を暴露し，各種の検討を行った。その結果，表面のポリマーの 被膜化は初期の乾燥条件の影響を受けること, ポリマーの添加や乾燥条件が厳しくなるほどセメントの水和は抑制さ れることなどが明らかとなり，圧縮強度には，セメントの水和が，曲げ強度にはポリマーの被膜化が支配的に関与し ていることが明らかとなった。また, 実際の断面修復材に使われている膨張材や収縮低隇剤を添加して寸法安定性試 験を行い，作用機構の異なる両材の併用がひび割れ抑制などに最も効果的であることなどを明らかとした。 キーワード: ポリマーセメントモルタル, ポリマーの被膜化, セメントの水和, 細孔構造, 強度, 中性化, 収縮補償
\end{abstract}

\section{1. はじめに}

1900 年初頭から市民生活を支える社会基盤の中核を なしてきた鉄筋コンクリートは，半永久的にメンテナン スフリーであると考えられていた。現に初期の構造物は 丁寧に材料を選び施工されているため現在でもその機能 を十分に果たしているものが多い1)。しかし，1980年代 以降，数十年しか経過していないコンクリート構造物， 例えば，新幹線のトンネルや高架橋コンクリートにおい てはく落事故が頻発している。これらの構造物の多くは 1960 年代以降の高度経済成長期に建造されたものであ り, 急速施工，大量打設の要求で導入されたコンクリー トポンプ車など施工機械の導入によるところが大きいと 言われている ${ }^{2)}$ 。このようにコンクリート構造物のはく 離・はく落事故が発生したことによってコンクリート構 造物の維持管理や補修・補強が必要であり, ライフサイ クルコストを最小限にするような各要素技術の検討が急 務であると考えられるようになった。

一方, 劣化したコンクリート構造物の補修工法として, 劣化部を取り除いた後には断面修復工法が有効な対策法 と考えられていた。しかし，補修した構造物も早期に再 劣化している事例が後を絶たない。これは適切な時期に 適切な方法で補修されなかったことが一因と考えられる。 また，主に適用されているポリマーセメントモルタル(以 下, PMM)については材料の持つ特性を十分に理解せず,
理想的環境下で得られる性能が現場でも発揮されるとし て, 実環境から受ける影響を考慮した補修を行わなかっ たことも一因であると考えられる。

そこで, 本研究では, 劣化したコンクリート構造物の 補修工法である PMM 系湿式吹付け工法について, 実環 境を想定した条件に試験体を暴露し, 細孔構造分析とセ メントの水和反応, ポリマーの被膜化の観点から評価す ることによって, 実環境から受ける影響について検討し た。さらに, 膨張材や収縮低減剤などの収縮補償材料が 実環境下で施工される断面修復材中でどのように機能し ているのかを検討した。

以上のことなどから本研究は, 実環境において断面修 復材として期待される品質を確保するための合理的な施 工方法にてついて検討したものである。

\section{2. 実験概要}

\section{1 使用材料および配合}

表ー 1 に使用材料を, 表一 2 に配合を示す。使用した ポリマーはノニオン系再乳化形粉末樹脂であり, ポリマ 一セメント比 $(\mathrm{P} / \mathrm{C})$ は $0 \%, 5 \%, 10 \%$ おび $20 \%$ とした(以 下，それぞれ NCM，P5，P10 およびP20 と略記する)。 PMM の配合は，壁面に $20 \mathrm{~mm}$ 厚で吹付け可能な配合を 選定したものであり，目標フロー值は $180 \pm 20 \mathrm{~mm}$ とし た。なお，寸法安定性の評価では，P5のみとし膨張材， 
収縮低減剤を添加して行った。表一 2 に各配合条件にお ける PMM のフロー值, 封緘材齢 28 日の圧縮強度を示す。

\section{2 試験体作製}

練混ぜは，強制攪挥型のモルタルミキサを使用し 5 分 間行った。試験体は，ポリマーを添加していない $\mathrm{NCM}$ は左官工法により, PMM は吹付け工法(吐出量約 $0.1 \mathrm{~m}^{3} / \mathrm{h}$, ノズル径 $8 \mathrm{~mm}$ ) で作製し, 直後から各条件に暴露した。

\section{3 暴露条件}

表一ろに設定した暴露条件を示す。風環境は，条件が 特に厳しい地下鉄坑内などでの施工を想定し $2 \mathrm{~m} / \mathrm{s}$ とし た(W 環境)。また, PMMにとって理想的な養生条件とし て水中養生後, 乾燥させる条件を設定し( SW 環境), さら に実環境を想定して $10^{\circ} \mathrm{C}$ 環境, $30^{\circ} \mathrm{C}$ 環境および初期の封 緘養生時間を変化させたものも設定した(SE 環境)。

\section{4 試験方法}

（1）水分蒸発量試験

$130 \times 130 \times 20 \mathrm{~mm}$ のアクリル製型枠を使用し，吹付け直 後からの質量変化を測定した。なおここでは初期のセ メントの影響を評価するため, セメントの代わりに水和 反応のない石粉(石灰石微粉末)を使用したものも対象と し,ポリマー添加率は石粉に対して質量比で5\%とした。

表 -1 使用材料

\begin{tabular}{|c|c|c|}
\hline 種類 & 記号 & 諸元 \\
\hline セメント & $\mathrm{C}$ & 普通ポ ルトランドセメント，密度 $3.15 \mathrm{~g} / \mathrm{cm}^{3}$ \\
\hline けい砂 & $\mathrm{S}$ & 粗粒率 $=1.71$, 密度 $2.60 \mathrm{~g} / \mathrm{cm}^{3}$ \\
\hline ポリマー & $\mathrm{P}$ & 酢酸ビニル・ベオバ・アクリル共重合樹脂 \\
\hline 混和剂 & SP & ポリカルボン酸系粉末高性能減水剂 \\
\hline 消泡剂 & DA & ポリエーテル系粉末型消泡剂 \\
\hline 膨張材 & EX & エトリ决仆-石灰複合系 \\
\hline 収縮低減剤 & SRA & 低級アルコールアルキレンオキシド付加物 \\
\hline
\end{tabular}

表 -2 配合

\begin{tabular}{|c|c|c|c|c|c|c|c|c|c|c|c|c|}
\hline \multirow{2}{*}{ No } & \multirow{2}{*}{$\begin{array}{c}\text { W/B } \\
(\%)\end{array}$} & \multirow{2}{*}{$\begin{array}{l}P / \mathrm{B}^{*} \\
(\%)\end{array}$} & \multicolumn{6}{|c|}{ 単位量 $\left(\mathrm{kg} / \mathrm{m}^{3}\right)$} & \multicolumn{2}{|c|}{$(\mathrm{C} \times \%)$} & \multirow{2}{*}{$\begin{array}{l}\text { Flow } \\
(\mathrm{mm})\end{array}$} & \multirow{2}{*}{$\begin{array}{c}\sigma_{28} \\
\left(\mathrm{~N} / \mathrm{mm}^{2}\right)\end{array}$} \\
\hline & & & $\mathrm{W}$ & C & $\mathrm{EX}$ & P & $S$ & SRA & SP & DA & & \\
\hline $\mathrm{NCM}$ & \multirow{7}{*}{38} & 0 & \multirow{7}{*}{233} & 614 & 0 & 0 & 1227 & 0 & \multirow{7}{*}{0.08} & \multirow{7}{*}{0.2} & 168 & 60.3 \\
\hline P5 & & 5 & & 614 & 0 & 31 & 1147 & 0 & & & 172 & 52.9 \\
\hline P10 & & 10 & & 614 & 0 & 61 & 1069 & 0 & & & 175 & 53.0 \\
\hline $\mathrm{P} 20$ & & 20 & & 614 & 0 & 123 & 907 & 0 & & & 189 & 35.0 \\
\hline P5E & & 5 & & 574 & 40 & 31 & 1147 & 0 & & & 172 & 53.1 \\
\hline P5S & & 5 & & 614 & 0 & 31 & 1132 & 6 & & & 170 & 53.1 \\
\hline P5ES & & 5 & & 574 & 40 & 31 & 1132 & 6 & & & 175 & 52.8 \\
\hline
\end{tabular}

${ }^{*} \mathrm{~B}=\mathrm{C}+\mathrm{EX}$ (本文中, $\mathrm{P} / \mathrm{B}$ は $\mathrm{EX}=0 \mathrm{~kg} / \mathrm{m}^{3}$ の場合, $\mathrm{P} / \mathrm{C}$ と表記する)

\section{表一 3 暴露条件}

\begin{tabular}{|c|c|c|c|c|}
\hline 条件名 & ${ }^{\circ} \mathrm{C}$ & 記号 & \multicolumn{2}{|c|}{ 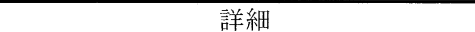 } \\
\hline 封縅-風 & & SW & \multicolumn{2}{|c|}{$\begin{array}{l}\text { 材齢 } 2 \text { 日まで封縅 } \rightarrow \text { 材齢7日まで水中 } \rightarrow \text { 風 } \\
\text { 速 } 2 \mathrm{~m} / \mathrm{s} \text { に暴露 }\end{array}$} \\
\hline 封縅 & & $\mathrm{S}$ & \multicolumn{2}{|c|}{ 成型後、ビニール袋内で封縅養生 } \\
\hline 気乾 & & $\mathrm{D}$ & \multicolumn{2}{|c|}{$\begin{array}{l}\text { 成型直後から恒温恒湿室内で } 65 \pm 5 \% \mathrm{RH} \text { 、 } \\
\text { 無風の条件で保管(自蒸発許容) }\end{array}$} \\
\hline 風環境 & 20 & W & \multicolumn{2}{|c|}{$\begin{array}{l}\text { 成型直後から風速 } 2 \mathrm{~m} / \mathrm{s} の \text { 風に暴露(地下鉄 } \\
\text { 坑内実測値と東京都平均風速を参考) }\end{array}$} \\
\hline \multirow{4}{*}{$\begin{array}{c}\text { 封縅 } \\
\qquad \\
\downarrow \\
\text { 風環境 }\end{array}$} & & SE6 & 封縅 6 時間 $\rightarrow$ & \multirow{4}{*}{$\begin{array}{l}\text { 風速 } 2 \mathrm{~m} / \mathrm{s} \\
\text { に暴露 }\end{array}$} \\
\hline & & SE12 & 封縅 12 時間 $\rightarrow$ & \\
\hline & & SE24 & 封縅 24 時間 $\rightarrow$ & \\
\hline & & SE48 & 封縅 48 時間 $\rightarrow$ & \\
\hline 低温封縅 & 10 & LS & \multirow{2}{*}{\multicolumn{2}{|c|}{ 成型後、ビニール袋内で封縅養生 }} \\
\hline 高温封縅 & 30 & HS & & \\
\hline 低温気乾 & 10 & LD & \multirow{2}{*}{\multicolumn{2}{|c|}{$\begin{array}{l}\text { 成型直後からチャンバー内で } 65 \pm 5 \% \mathrm{RH} \text { 、 } \\
\text { 無風の条件で保管(自然蒸発許容) }\end{array}$}} \\
\hline 高温気乾 & 30 & HD & & \\
\hline
\end{tabular}

(2) 細孔径分布測定

$180 \times 180 \times 20 \mathrm{~mm}$ のアクリル製型枠を使用し，吹付け 後, 直ちに材齢 28 日まで各条件に暴露し, 表面から $10 \mathrm{~mm}$ までの部分から試料を採取した。試料は $2.5 〜 5 \mathrm{~mm}$ に粗 粉砕し, アセトンで水和を停止した後, D-乾燥してから 水銀圧入ポロシメーターで細孔径分布を測定した。なお, 測定結果は配合毎に細骨材量が異なることからポリマー セメントペースト当りの有効細孔量に変換した。また, 評価は, 細孔の量を表す有効総細孔量(TPV) と質を表す 空隙係数 $(\mathrm{Zp})$ を定義して行った。ここで， $\mathrm{Zp}$ とは $50 \mathrm{~nm}$ よりも大きい細孔 $\mathrm{P}_{\mathrm{B}}$ を $50 \mathrm{~nm}$ よりも小さい細孔 $\mathrm{P}_{\mathrm{S}}$ で除 した值 $\left(\mathrm{P}_{\mathrm{B}} / \mathrm{P}_{\mathrm{S}}\right)$ とした。

\section{（3）熱分析・X線回折}

セメントの主成分である $\mathrm{C}_{3} \mathrm{~S}$ や $\mathrm{C}_{2} \mathrm{~S}$ は，水和反応によ りケイ酸カルシウム水和物 $(\mathrm{C}-\mathrm{S}-\mathrm{H})$ と水酸化カルシウム $(\mathrm{CH})$ になる。前者は結晶性がそしく，化学組成も広範囲 で変化する。一方, 後者は結晶性も良く, 組成も一定の 化合物であると言われている。一般的に材龄の進行や養 生条件に応じたセメントの水和の定量評価は，これらの 化合物に着目して検討されることが多く，特に $\mathrm{CH}$ に着 目して検討したものがある ${ }^{3)}$ 。そこで，本研究では，こ れを参考とし各種環境条件下において， P/C を変化させ た PMM 中のセメントの水和の進行程度を定量的に評価 するため，結晶性の良い $\mathrm{CH}$ の生成状態を熱分析と X 線 回折法の 2 つ手法により測定した。試料は, 細孔径分 布測定用と同じ小片を微粉砕したものである。熱分析に ついては, $\mathrm{CH}$ が $400^{\circ} \mathrm{C}$ 付近で脱水現象 $\left(\mathrm{Ca}(\mathrm{OH})_{2} \rightarrow\right.$ $\left.\mathrm{CaO}+\mathrm{H}_{2} \mathrm{O}\right)$ を起こすことから, この付近のピーク面積 $\mathrm{PA}_{\mathrm{DTA}}$ により評価した。一方, $\mathrm{X}$ 線回折 $(\mathrm{Cu}-\mathrm{K} \alpha, 40 \mathrm{kV}$, $40 \mathrm{~mA}$ )により $\mathrm{CH}$ 生成量の反射ピークである $2 \theta=18^{\circ}$ 付 近の回折線強度の大きさに着目して評価した。

(4) 圧縮・曲げ強度試験

一般的なモルタルを対象とした強度試験は, JIS A 1171 に準拠して $40 \times 40 \times 160 \mathrm{~mm}$ の試験体を対象として行わ れる。しかし，本研究では図－1に示すように $20 \times 20$ $\times 80 \mathrm{~mm}$ の試験体を対象とした。それには 2 つ理由が ある。ひとつは一般的な断面修復材が $20 \mathrm{~mm}$ 厚程度で施 工させること，もうひとつは，試験体に対する環境影響 を全断面で一定とするためである。

試験は, 立掛けたパッドに材料を吹付けた後, 型枠内 に材料を充填し, 直ちに各環境条件に暴露し, 材齢 2 日 で脱型後, さらに継続して材齢 28 日まで暴露した。試験 は, 材齢 28 日において各条件曲げ試験 3 体, 圧縮試験は 曲げ試験後の 6 体を対象として実施した。

（5）促進中性化試験

中性化試験は, $40 \times 40 \times 160 \mathrm{~mm}$ の試験体を対象とした。 試験体は, 強度試験と同じ手順で作製し, 脱型後, 直ち に打設面以外の 5 面をシールし,材齢 28 日まで各条件に 暴露した。その後, $20{ }^{\circ} \mathrm{C}, 60 \% \mathrm{RH}, \mathrm{CO}_{2} 10 \%$ の中性化促 
進試験槽に移動し 28 日後にフェノールフタレイン法に より中性化深さを測定した。

（6）寸法安定性試験

寸法安定性試験の概要を図ー 2 に示す。対象としたの は $300 \times 300 \times 60 \mathrm{~mm}$ のコンクリート平板 $\left(\sigma_{28}=48 \mathrm{~N} / \mathrm{mm}^{2}\right)$ で あり，実際の部分断面修復を想定した拘束条件を再現す るため, 試験体中央部を $180 \times 180 \times 20 \mathrm{~mm}$ の範囲でチッピ ング処理して除去した。その後, 浮石や余分な粉分を取 り除き,ドライアウト防止のため水を散布し 20 分間静置 した。試験体には, まず約 $5 \mathrm{~mm}$ の厚さにモルタルを施 工し中央に 24 時間事前吸水処理した低弾性ゲージ(弾性 係数 : 約 $1.5 \mathrm{~N} / \mathrm{mm}^{2}$ )を設置した。その後 $15 \mathrm{~mm}$ 厚まで施 エした。さらに同じゲージを図に示すように方向を変え て設置し，厚さ $20 \mathrm{~mm}$ になるまで連続的に施工した。作 製した試験体は直ちに $\mathrm{W}$ 環境に移動し連続的に発生し た実ひずみを計測した。つまり，2 枚のゲージを使用し 断面方向に対して表面部(-5mm) と内部(-15mm)の 2 箇所 において発生した実ひずみを計測した ${ }^{4), 5) 。 ~}$

\section{PMM 中のポリマーの被膜化とセメント水和}

\subsection{PMM 中のポリマーの被膜化}

図ー3にPMM および石粉を使用した場合 $(\mathrm{Lm})$ の D お よび W 環境での経過時間と質量減少量の関係を示す。一 般に乾燥を受ける水性塗料などは，時間当たりの蒸発量 が一定となる恒率乾燥域と時間当たりの蒸発量が徐々に 少なくなる減率乾燥域が存在寸ると言われている ${ }^{6)}$ 。 れを参考とし本研究では，この恒率乾燥域の終点を表面

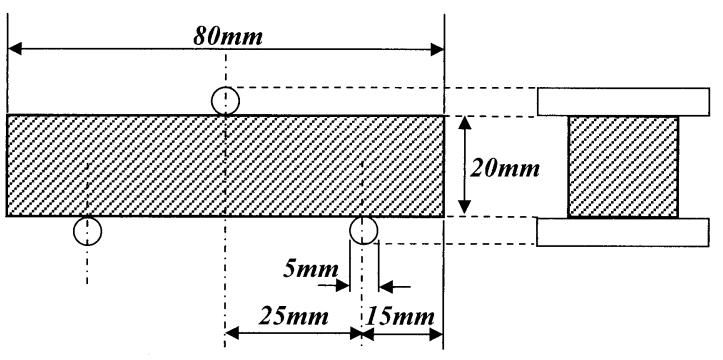

図-1＼cjkstart曲げ強度測定の載荷状態

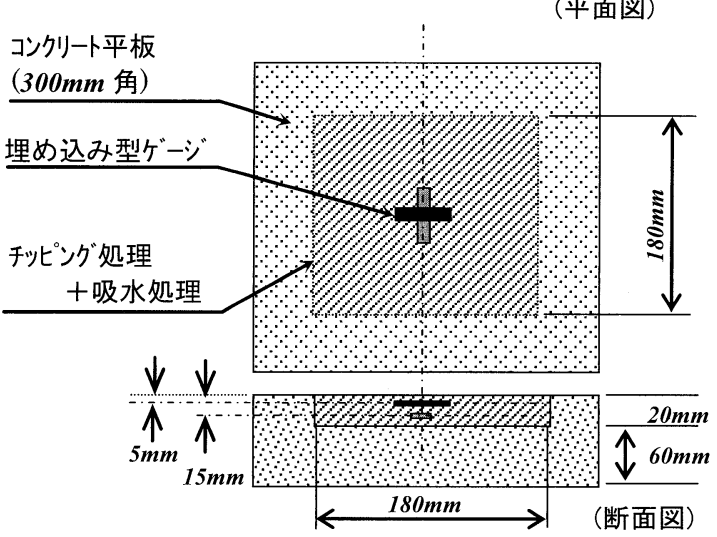

図一２＼cjkstart法安定性試験概要
部分でのポリマーの見掛けの被膜形成点 $\mathrm{T}_{\mathrm{C}}$ と定義した。 図中の直線は，恒率乾燥域における時間と質量減少量の 関係を示したものであるが，この回帰直線算出のために 使用した最後のデータを被膜形成点 Tc であるとした(図 中の点線矢印)。

$\mathrm{P} 5$ の $\mathrm{W}$ 環境の $\mathrm{T}_{\mathrm{C}}$ が 0.3 日程度であったのに対し, 徐々 に水分が逸散する D 環境では 1.2 日程度と長くなった。 また，石粉を使用した場合 $(\mathrm{Lm})$ とセメントを使用した $\mathrm{PMM}$ を比較すると D 環境では $\mathrm{T}_{\mathrm{C}}$ に差があったが, $\mathrm{W}$ 環 境ではその差は少なかった。つまり，初期に急激な乾燥 を受ける環境では，被膜化に及ぼすセメントの水和の影 響は少ないと言える。

この結果を基に乾燥条件下における PMM 表面でのポ リマーの被膜化について考察寸る。図ー4に W 環境にお ける PMM 表面部でのポリマーの被膜化の概念を示す。 なお，ここではセメントの水和を無視し，既往の研究で 示されているセメントの水和とポリマーの被膜化の進行 概念を参考にして, 表面部でのポリマー粒子の動きに着 目した ${ }^{7)}$ 。この図に示すように水分の蒸発に伴って表面 方向に移動すると考えられるポリマー粒子は，急激な乾 燥を受けるほど自由に動き, より多くの粒子が表面方向 に移動して互いの距離を小さくすることで被膜はより密 実化，高硬度化するものと考えられる。

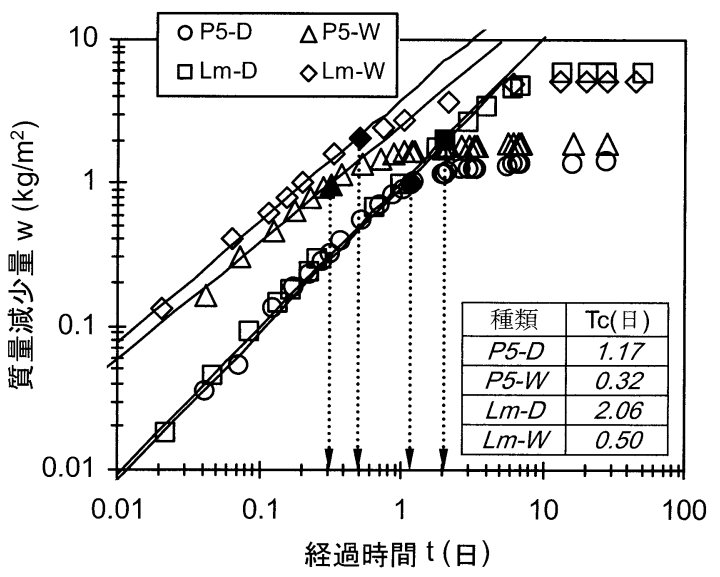

図-3 経過時間と質量減少量の関係

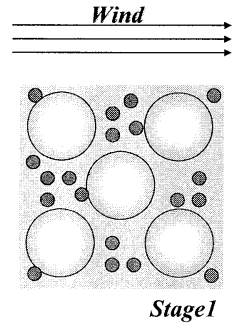

暴露直後, ポリマ 一粒子が水の中に 浮遊した状態

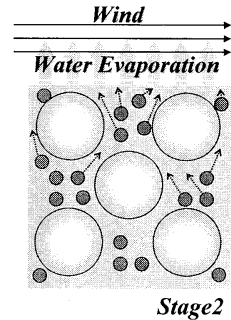

水分が表面から蒸 発し, 内部の水分が 表面方向に移動し 始める。
セメント・ポリマー、水

図ー4 PMM 表面でのポリマーの被膜化の概念

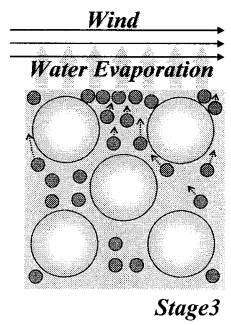

水分と伴に表面部に ポリマーが移動し, 徐々にポリマー間の 距離が小さくなり被 膜化する。 


\subsection{PMM 中のセメントの水和}

図一 5 に各種環境条件における $\mathrm{P} / \mathrm{C}$ とセメントの水和 の指標となる $\mathrm{PA}_{\mathrm{DTA}}$ の関係を示寸。PMM は乾燥条件が 厳しくなるに従い水和に必要な水分が逸散することから セメントの水和の進行は抑制される傾向にあった。例え ば, P10の条件で $\mathrm{S}$ 環境を基準とすると D環境では 71\%, $\mathrm{W}$ 環境では $67 \%$ の水和率となった。 $\mathrm{P} / \mathrm{C}$ の影響は, $\mathrm{P} / \mathrm{C}$ が高くなるに従い $\mathrm{PA}_{\mathrm{DTA}}$ の值が小さくなり, つまりセメ ントの水和は抑制される傾向にあり，これは既往の研究 とも一致した結果となった ${ }^{77,8), 99}$ 。次に，これを定量的に 評価する。図一6に $\mathrm{S}$ 環境における $\mathrm{P} / \mathrm{C}$ と $\mathrm{NCM}$ に対す るセメントの水和比率 $\mathrm{H}$ の関係を示す。式(1), (2)に示 すように熱分析 $\left(\mathrm{PA}_{\mathrm{DTA}}\right)$ およびX線回折(XRD)の結果から $\mathrm{P} / \mathrm{C}$ が 1\%増加するとセメントの水和は平均約 $2 \%$ 抑制さ れると考えられる。

$$
\begin{aligned}
& P A_{D T A}: H(\%)=-2.5 \times(P / C)+100 \\
& X R D: H(\%)=-1.5 \times(P / C)+100
\end{aligned}
$$

\subsection{PMM の細孔構造}

PMM の細孔構造にはセメントの水和とポリマー被膜 化が大きく影響していると考えられる。図ー7に細孔径 分布の測定結果を示す。

図ー8に各種環境条件における TPVを, 図ー9に同じ $く \mathrm{Zp}$ を示す。 $\mathrm{SW}$ と $\mathrm{S}$ 環境ではいずれの $\mathrm{P} / \mathrm{C}$ でも細孔構 造の大きな違いは認められなかった。一方，DとW 環境 ではいずれの配合でも細孔構造は粗大化する傾向にあり， 特に, P5 は Zp が大きくなり細孔構造は粗大化していた。

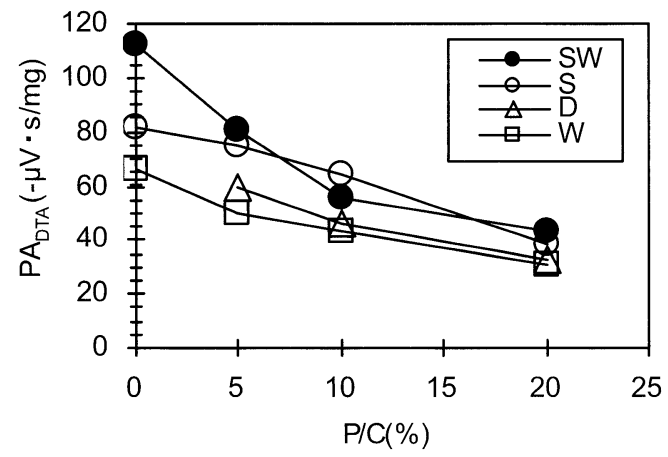

図ー $5 \mathrm{P} / \mathrm{C}$ と $\mathrm{PA} \mathrm{A}_{\mathrm{DTA}}$ の関係

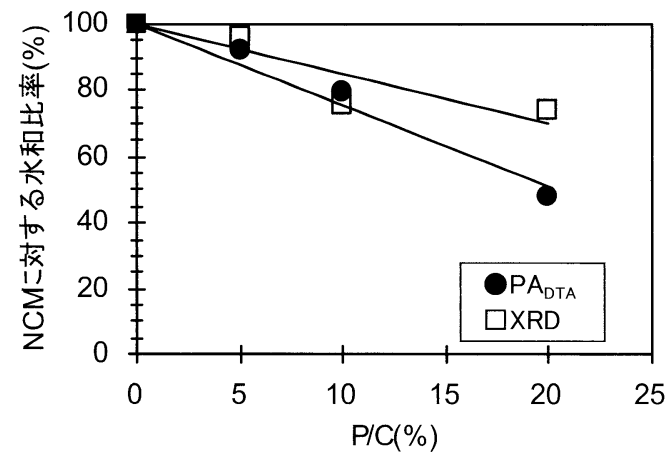

図ー6 P/C と NCMに対するセメント水和率の関係
しかし，P/C が高い場合には乾燥条件でも TPV と Zp と もに低い值を示し，細孔構造は緻密化していた。前述の とおり PMM 中のポリマーは，セメントの水和を抑制す る傾向にあった。しかし，高 $\mathrm{P} / \mathrm{C}$ の条件で組織が緻密化 していたことから，これはセメントの水和によるもので はなく，ポリマーの被膜充填効果によるものと考えられ る。さらに図ー10に既往の研究を参考として PMM 中の インクボトル細孔以外の部分を連続した状態にあるとし て算出した連続空隙率を示す ${ }^{10)}$ 。高 $\mathrm{P} / \mathrm{C}$ ほど細孔の連続 性は低下しており，ポリマーの添加は劣化因子の侵入抑 制に対しても大きな効果が期待できると考えられる。
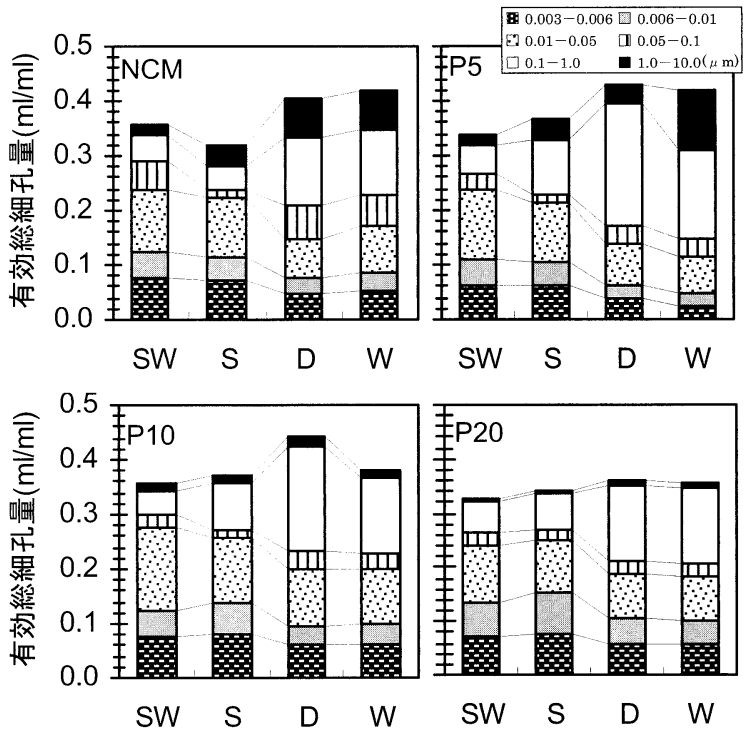

図－７細孔径分布測定結果

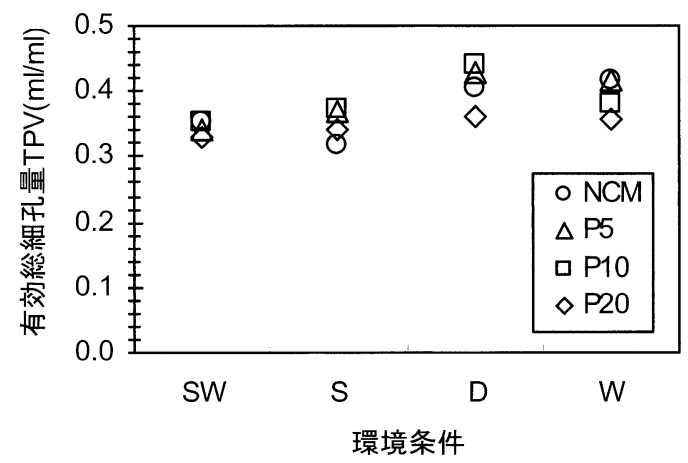

図-8＼cjkstart環境条件別の有効総細孔量

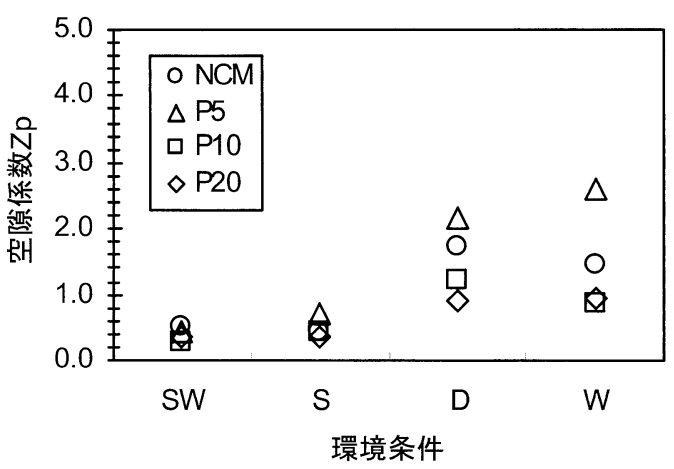

図-9 環境条件別の空隙係数 


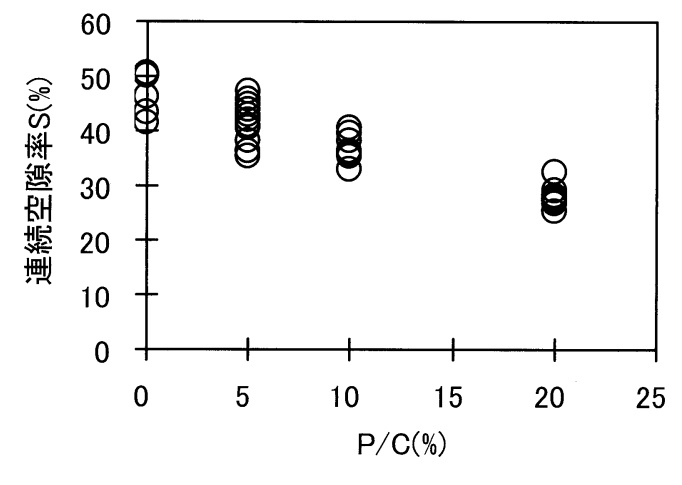

図-10 P/C と連続空隙率の関係

\section{PMM の強度, 中性化抵抗性に関する検討}

\subsection{PMM の曲げ・圧縮強度に関する検討}

図－11, 12 に水分の蒸発を許容していない $\mathrm{S}$ 環境に暴 露した試験体の $\mathrm{P} / \mathrm{C}$ と曲げ・圧縮強度の関係を示す。水 分を蒸発させずに養生した場合，曲げ強度は P/C の影響 はほとんじ受けず，温度の影響を受けて養生温度が高い ほど曲げ強度は高くなる傾向にあった。また，圧縮強度 は温度の違いによる影響はほとんど受けていなかった。 しかし，P/C の影響は大きく，P/C が高くなるに従い压 縮強度は低下寸る傾向にあった。

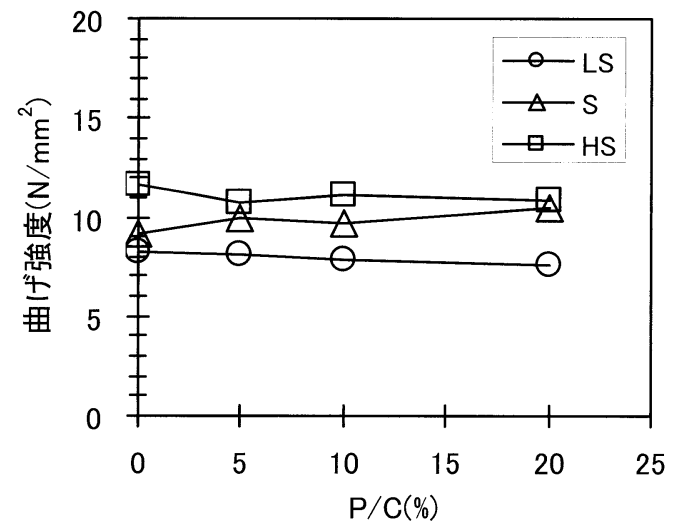

図-11 P/C と曲げ強度の関係(封緘条件)

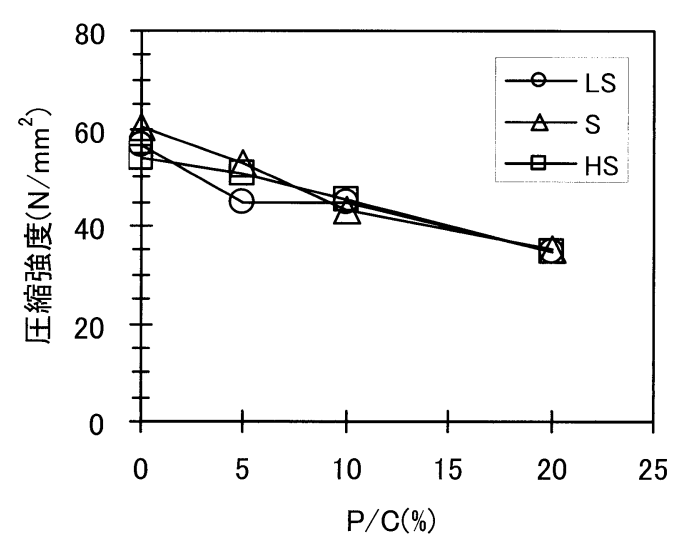

図-12 P/C と圧縮強度の関係(封緘条件)
図ー13，14 に SW 環境を含めた乾燥条件下における $\mathrm{P} / \mathrm{C}$ と曲げ・圧縮強度の関係を示す。このなかでは，7 日間水中養生し, その後乾燥条件とした SW 環境が曲げ 強度，圧縮強度ともにいずれの $\mathrm{P} / \mathrm{C}$ においても最大とな り，このような養生条件が PMM の強度発現性にとって 好ましい養生状態であると考えられる。P/Cについては, これが高くなるに従い曲げ強度は高くなり，圧縮強度は 低下する傾向にあった。SW 環境以外の成型後, 直ちに 乾燥状態となる環境では, 前述した封緘条件とは逆の傾 向となった。つまり，曲げ強度は $\mathrm{P} / \mathrm{C}$ の影響を大きく受 けており, 逆に圧縮強度は $\mathrm{P} / \mathrm{C}$ の影響はほとんど受けず にほぼ同程度となった。

これらの結果を基に PMM の曲げ，圧縮強度について ポリマーの被膜化とセメントの水和の進行を考慮して考 察する。まず，曲げ強度については，最も影響を及ぼし ているのはポリマーの存在であると考えられる。一般的 に PMM の曲げ強度や接着強度は, マトリックス中のポ リマーの被膜化と被膜自体の強度が高くなることで改善 されると考えられている ${ }^{7)}$ 。したがって, 水分を蒸発さ せない $\mathrm{S}$ 環境では, ポリマーはマトリックス中に存在し ているものの，被膜自体の強度は比較的低い状態である と考えられ，このような条件では, 曲げ強度の増加には 寄与していないと考えられる。

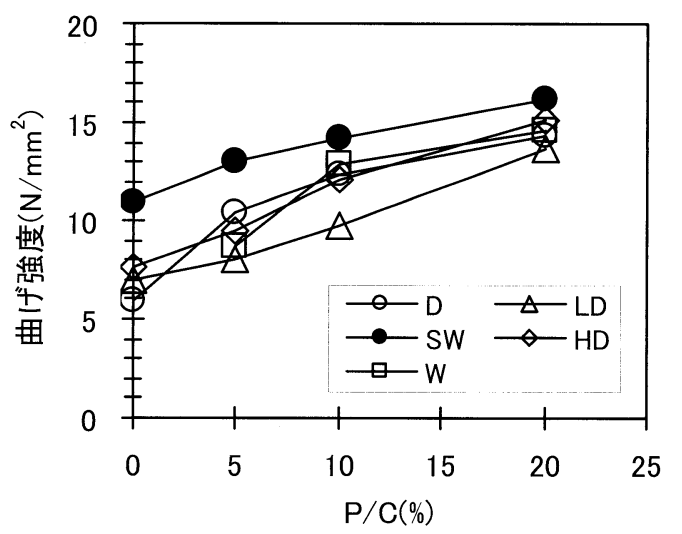

図一13 P/C と曲げ強度の関係(乾燥条件)

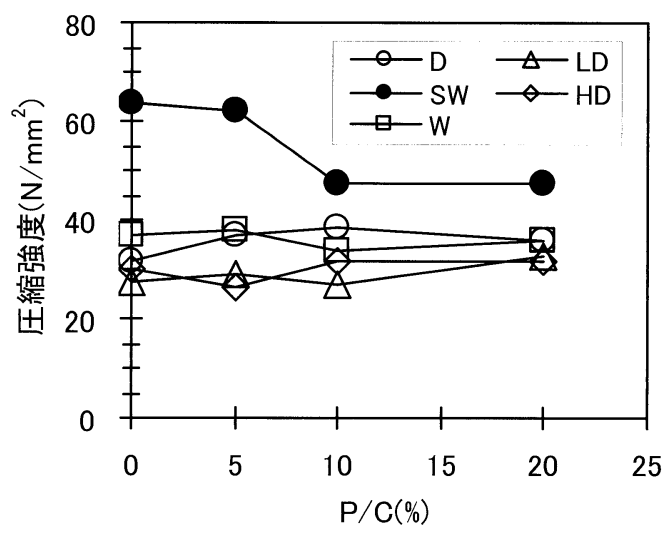

図-14 P/C と圧縮強度の関係(乾燥条件) 
一方，乾燥する条件の場合には，P/C が高くなるに従 い曲げ強度は増加する傾向にあった。前述のようにこの 条件では, 乾燥状態となるため早期に水分が蒸発しセメ ントの水和は抑制される傾向にあった。しかし，図－4 で示したようにポリマーの被膜は水分の蒸発によって, また, 温度が高くなることなどにより高硬度化し, マト リックスと骨材間の接着性を向上するなどの効果を発揮 し， $\mathrm{P} / \mathrm{C}$ が高くなるほど曲げ強度が増加したものと考え られる。

圧縮強度については，ポリマーの被膜形成が卓越する 乾燥条件において大きな影響がなく, 逆にセメントの水 和が卓越する封緘養生において $\mathrm{P} / \mathrm{C}$ の影響が顕著に現れ， ポリマーがセメントの水和を抑制していることも影響し ていた。そこで, 圧縮強度と関係が深いとされているマ トリックス中の空隙構造について考察する。一般的に圧 縮強度はマトリックス中のある径以上の空隙と高い相関 性があると言われている。

図ー15に $0.05 \mu \mathrm{m}(50 \mathrm{~nm})$ 以上の細孔量 $\mathrm{P}_{\mathrm{B}}$ と材齢 28 日 圧縮強度の関係を示す。ここで, セメント系などの多孔 質材料の空隙と強度に関していくつかの関係式が提案さ れているが，そのひとつである Ryshkewitch の式(3)を本 実験結果に適用してみる ${ }^{11), 12) 。 ~}$

$$
\sigma_{c}=\sigma_{0} \exp \left(-b P_{B}\right)
$$

ここで, $\sigma_{c}$ : 圧縮強度, $\sigma_{0}$ : 空隙がゼロの時の圧縮 強度, $P_{B}$ : 細孔量, $b:$ 実験定数

$\mathrm{P} / \mathrm{C}$ 毎に式(3)に従って近似された線を同図に示すとと もに，それぞれ関係式を式(4)〜(7)に示す。

$$
\begin{array}{r}
N C M: \sigma_{C}=85.1 \exp \left(-3.3 P_{B}\right) \\
\text { P5: } \sigma_{C}=75.9 \exp \left(-2.9 P_{B}\right) \\
\text { P10: } \sigma_{C}=54.7 \exp \left(-2.1 P_{B}\right) \\
\text { P20: } \sigma_{C}=42.8 \exp \left(-1.4 P_{B}\right)
\end{array}
$$

図中の近似した線に着目して考察すると, いずれの $\mathrm{P} / \mathrm{C}$ においても $0.05 \mu \mathrm{m}(50 \mathrm{~nm})$ 以上の細孔量 $\mathrm{P}_{\mathrm{B}}$ が多くなる に従い圧縮強度は低下しており, 初期の水分の蒸発など によりセメントの水和が進まず細孔構造が粗大化したこ とによりと圧縮強度が低くなったと考えられる。

さらに詳細に結果を検証する。同じ圧縮強度で比較し た場合, $\mathrm{P} / \mathrm{C}$ が高くなるに従い $\mathrm{P}_{\mathrm{B}}$ は徐々に小さくなる傾 向にあった。これは $\mathrm{P} / \mathrm{C}$ が高くなるほど細孔構造は緻密 化するが，圧縮強度の増進には寄与しないことを示して いると考えられる。つまりポリマーの添加により PMM 中の細孔構造は緻密化するものの, 圧縮強度の増加に寄 与寸ると言われている C-S-H などの水和物の生成を促し

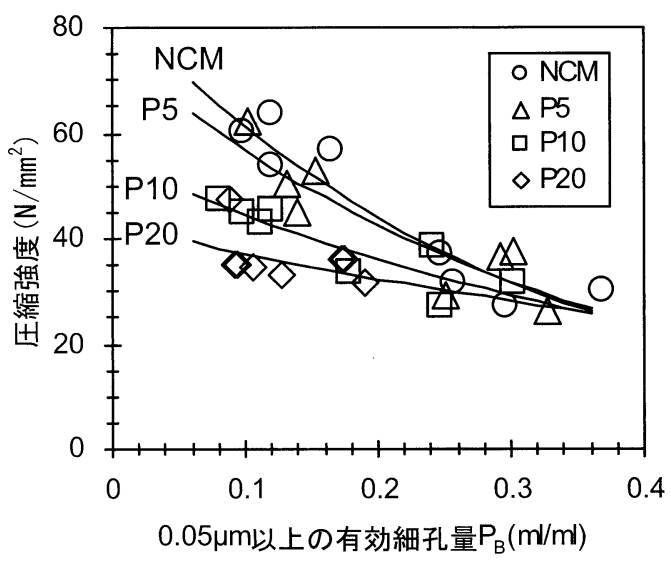

図-15 $0.05 \mu \mathrm{m}$ 以上の有効細孔量と圧縮強度の関係

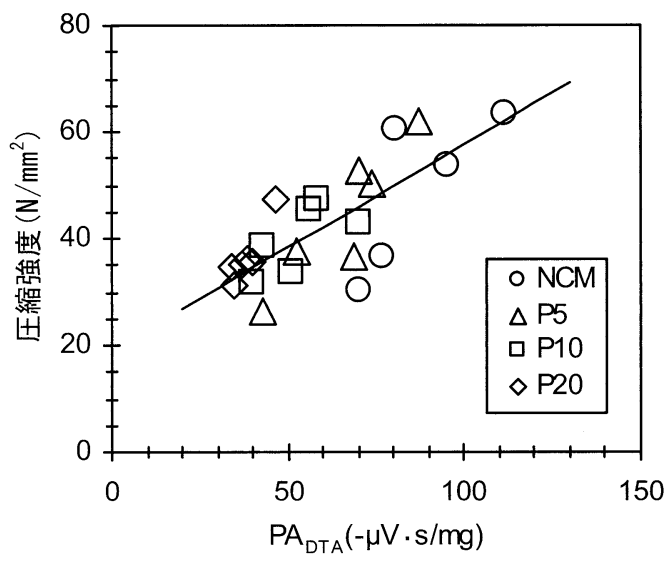

図ー16 PA $P$ DTA と圧縮強度の関係

ているような状態ではないと考えることができる。

特に, $\mathrm{P}_{\mathrm{B}}=0.3 \sim 0.4$ 付近のデータは, 乾燥条件に暴露し

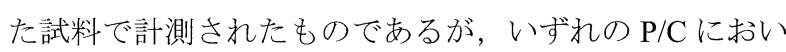
ても強度は同程度となっており, 初期の乾燥により水分 が失われセメントの水和が抑制された条件ではポリマー の存在，つまりポリマーの被膜が圧縮強度に及ぼす影響 は少ないと考えることができる。

図ー16にセメントの水和の程度を示す $\mathrm{PA}_{\mathrm{DTA}}$ の值と圧 縮強度の関係を示す。この図に示すように，両者の関係 には若干のばらつきは認められるが，ほぼひとつの傾向 として両者の関係を示すことができる。このことからも ポリマーの存在よりもセメントの水和のほうが圧縮強度 に大きく寄与していると言える。

以上のことより PMM の圧縮強度は, セメントの水和 が支配的であり，逆に，曲げ強度には内部のポリマーが 骨材とマトリックスを接着する有効な働きをするため, ポリマーの被膜化が支配的であると考えられ，乾燥する ほど被膜の硬度が高くなるとした図ー4の概念がこのよ うな状態を表現できているものと考えられる。 


\subsection{PMM の中性化抵抗性に関する検討}

図-17に各環境条件別の促進中性化深さを示す。なお， $\mathrm{S}$ 環境ではいずれの条件でも中性化は進行しなかった。 Dおよび W 環境ではポリマーを添加していない NCM は 中性化に対する抵抗が低くなった。

一方, PMM では P/C が高くなるに従い, 空隙の連続 性を低下させることなどポリマー添加の効果により中性 化の進行は抑制される傾向にあり, P5 でも相当の抑制効 果が発揮されていた。

さらに，P5 のみであるが実環境を想定した条件(SE)で は，初期の数時間だけ封縅養生することにより中性化深 さが大きくなった。図ー18 に示した TPV および Zp の值 からも細孔構造が粗大化していたことが確認できている。 この中性化に関する試験結果を図ー4のポリマーの被膜 化の概念図により考察する。例えば，SE6 の場合，この 初期の数時間はセメントの物性に大きく影響する凝結時 間に相当する。この間，封縅養生したことによりセメン トの水和はある程度進行したと考えられる。しかし,その 状況から風に曝され表面から水分が蒸発したとしても， 硬化体中の水分の移動(蒸発)は緩慢であり，同様にポリ マ一粒子の表面への移動も少ないものと考えられる。結 果として表面部の被膜も不完全なものとなり，さらに，

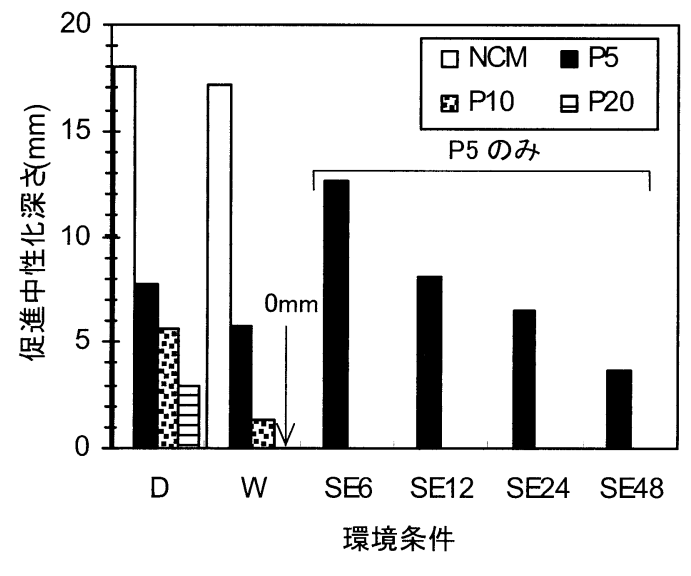

図-17 各種環境条件別の中性化深さ

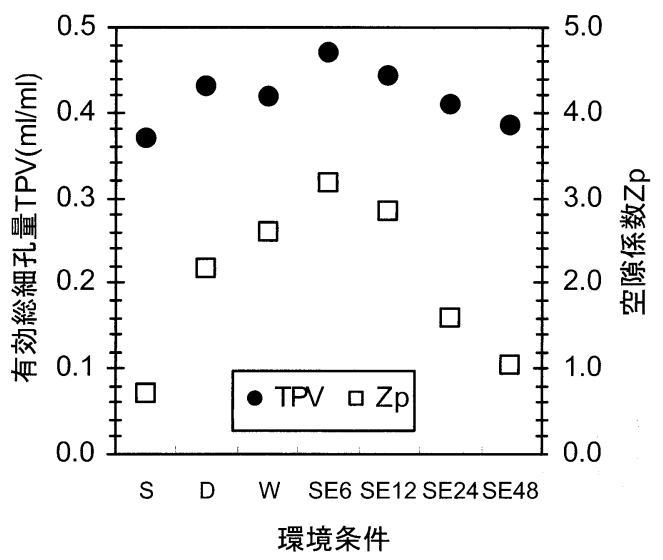

図一18 各種環境条件別の有効細孔量と空隙係数
その段階からも徐々に水分が蒸発するためセメントの水 和が抑制されて細孔構造が粗大化するため中性化抵抗性 が低くなったと考えられる。

以上のことより，図ー4で示した水分の移動(蒸発)に 伴うポリマー粒子の被膜化は初期の養生条件により大き く変化するものと考えられる。

\section{5. 実環境下における寸法安定性に関する評価}

図ー19 および図－20 に拘束条件下における内部およ び表面部のひずみを示す。成型直後から乾燥状態となる 条件では，ポリマーを添加していない NCM が最も早く 収縮ひずみが発生し, 暴露後約 40 分で圧縮側から収縮側 に移行し，その後も徐々に大きくなり，対象とした 5 配 合の中で最も収縮ひずみ量が多くなった。

一方，PMM は，内部よりも表面部の方がひずみは大き くなるものの，このような拘束条件においては NCM よ りも PMM の方が最終的な収縮ひずみ量は小さくなった。 これには,水分蒸発量の違いのほかに, コンクリート平板 との接着力や硬化時の弾性係数などが影響していると考 えられ, つまり PMM の方が NCM よりも平板との接着 力が高く，また，初期段階での弾性係数が小さいことか ら発生するひずみ量としては小さくなったものと考えら れる。このことなどから母材コンクリート界面とのひび 割れの抑制にもポリマーが効果を発揮するものと考えら れる。また, 計測した期間における収縮ひずみとしては,

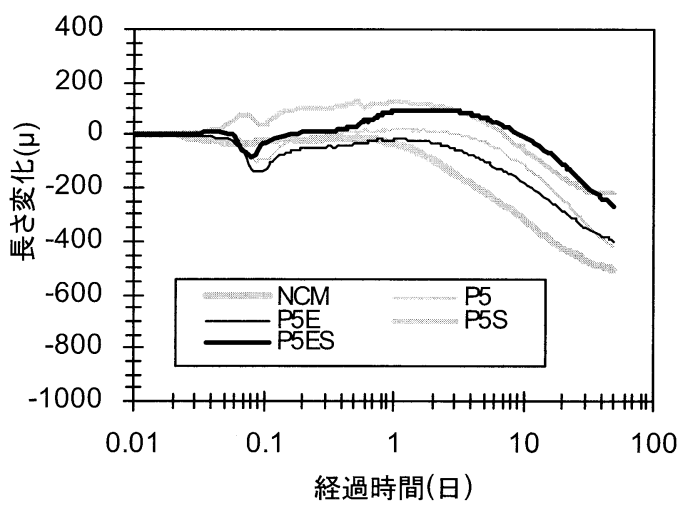

図-19 経過時間と長さ変化(内部)

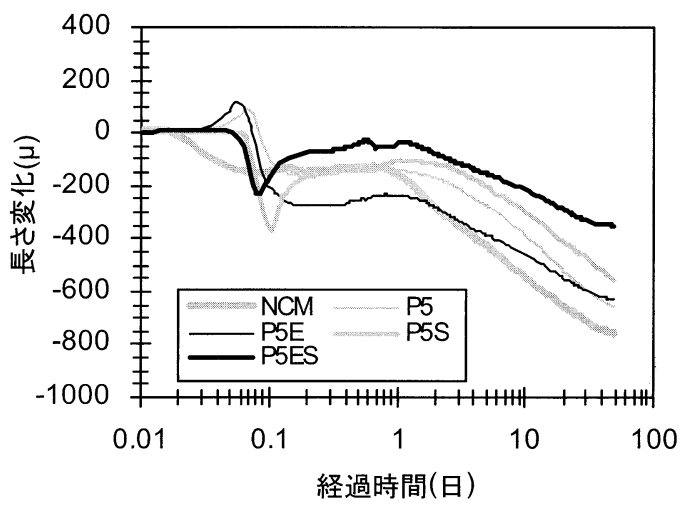

図一20＼cjkstart経過時間と長さ変化(表面) 
膨張材および収縮低減剤を併用した P5ES が最も小さく なった。

図ー21に膨張材および収縮低減剂を添加していない P5 のひずみ量から P5E，P5S および P5ES のひずみ量を それぞれ差し引いた值, つまり, 両材料の添加によって 収縮を補ったと考えられる収縮補償量を示す。

膨張材を単独で添加した場合(P5E), 極初期材齢におけ る収縮抑制効果はあまり期待できず，ある程度時間が経 過してから，つまり膨張材の作用を受け止められるだけ の骨格が形成されてから収縮補償効果が発揮されていた。 極初期材齢において収縮ひずみが大きくなったのは，水 分が蒸発する条件において，セメントとともに膨張材が 水和反応を始めたことにより内部の水分が多量に消費さ れたことなども影響していたと考えられる。仮に断面修 復材に膨張材を単独で添加することを想定した場合，養 生が不充分で乾燥を受けると, 表面に収縮ひび割れ発生 の可能性が高くなると考えられる ${ }^{13)}$ 。

収縮低減剂を単独で添加した場合は(P5S), 直ちに水分 が蒸発する条件であることから材齢初期から収縮抑制効 果が発揮されていた。しかし，長期的にはその効果は僅 かずつではあるが低下する傾向にあった。これは表面か ら蒸発する水分量が時間の経過とともに徐々に少なくな り, 収縮低減剤の効果が発揮できない状態となったと考 えられる。

両材を併用した場合には(P5ES), 相乗効果により最も 抑制効果が発揮され, 測定した材齢 50 日時点で無添加よ りも $300 \mu \mathrm{m}$ も収縮ひずみが小さくなった。しかし, 前 述したが，その効果の発揮時期については，一般的な型 枠内に打設されるコンクリートの場合とは異なる傾向で あり，施工対象面積に対して厚さが薄いような断面修復 工法において, 特に確実な養生条件が期待できずに内部 の自由水が蒸発してしまう条件での施工においては, 補 償機能の異なる両材の併用が最も望ましく, 初期材齢に おいては収縮低減剂がより効果的に機能し，長期的には 膨張材がその機能を有効に発揮して断面修復材に発生す る可能性のあるひび割れを抑制するものと考えられる 14), 15)

実際の補修工事を想定した断面においてひび割れの 発生する可能性の高い時期は, 表面と内部のひずみ差が 大きくなるときであると考えることができる。図一22に 経過時間と表面および内部のひずみ差を示す。このひず み差が大きくなったのは材齢 0.1 日(約 2〜3 時間)程度の 比較的早い段階と，さらに時間が経過した 5〜10日の間 であった。特に, NCM に比べて PMM は初期に比較的大 きなひずみ差を生じていた。これには，前述したような 表面付近のポリマーの被膜形成過程が収縮ひずみを大き

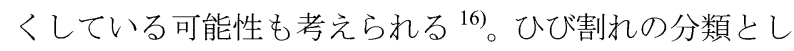
ては，前者はプラスチック収縮ひび割れと判断され，コ テ等による仕上げ作業で改善されているものであり，一

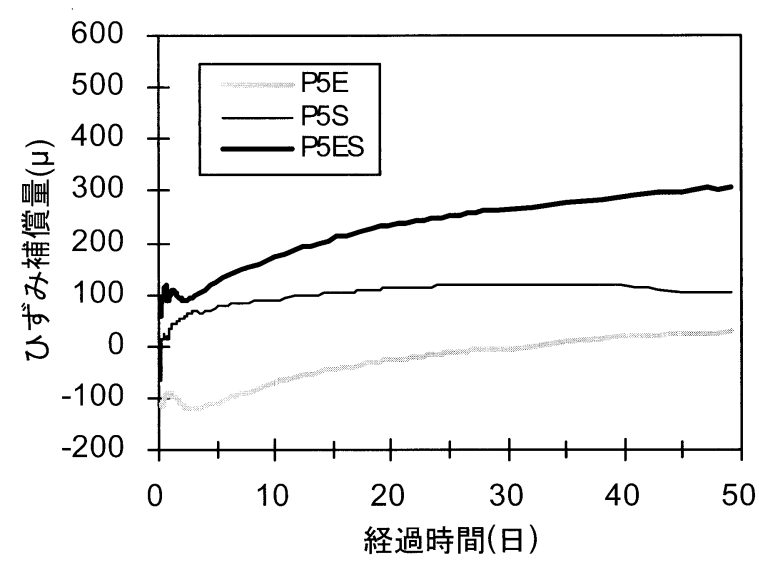

図一21 経過時間と各材料のひずみ補償量

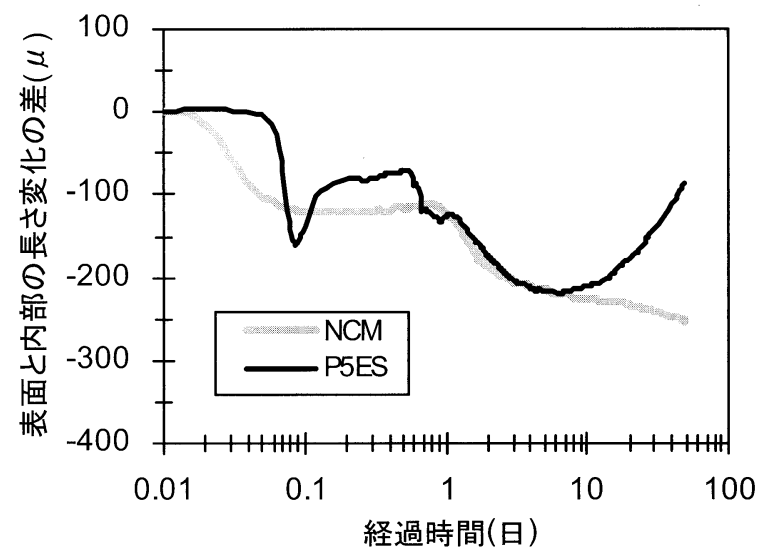

図一22 経過時間と表面と内部のひずみ差

方, 後者は一般的な乾燥収縮ひび割れとして顕在化する 可能性があり, 補修後の再劣化につながる可能性の高い ものである。例えば，文献 17)には，コンクリートに発 生する可能性のあるプラスチック収縮ひび割れの目安と して環境条件に応じた水分蒸発速度 $1 \mathrm{~kg} / \mathrm{m}^{2} / \mathrm{h}$ という值を 示している。しかし, PMM 系断面修復工法においては, 型枠に保護されることが少ないため施工直後から直接環 境の影響を受け，特に，PMM 系材料を断面修復工法に 適用する場合には，これよりも少ない蒸発速度でもプラ スチック収縮ひび割れが発生する可能性が考えられる。

以上，実際の現場で想定される環境条件下において， 膨張材や収縮低減剂のひび割れ抑制効果について検討し た。その結果，実環境下での補修工事を想定した場合， 収縮低減剤の効果は比較的初期段階から, また, 膨張材 は凝結硬化がある程度進んだ後, 継続的に比較的長期間 に渡ってその効果が持続することが確認できた。そして 一般的に言われているように膨張材, 収縮低減剤の併用 は断面修復材の耐久性確保のためには適切な材料選定で あることが確認できた。なお，PMM 系材料は，環境条 件によっては初期のプラスチック収縮ひび割れが大きく なる可能性があるため施工に際しては注意が必要である と考えられる。 


\section{6. まとめ}

本研究では, 限られた材料を対象としているが, PMM 系断面修復材の環境影響について検討した。本研究で得 られた主な知見を以下に示す。

（1）施工直後の PMM 表面からの水分蒸発速度が速い ほよ゙より多くのポリマー粒子が表面に移動して密 実な被膜を形成するものと考えられる。

（2）乾燥条件が厳しくなるに従いセメントの水和は抑 制され，また，ポリマー添加率が高くなるに従いセ メントの水和は抑制される傾向にあった。定量的に は $\mathrm{P} / \mathrm{C}=1 \%$ にさ約 $2 \%$ 抑制される傾向にあった。

（3）乾燥が進む条件では PMM の細孔構造は粗大化す る傾向にあった。一方，P/C が高くなるに従いセメ ントの水和は抑制されるが，ポリマーの充填効果に より細孔構造は緻密化し，空隙の連続性も低下する 傾向にあった。

（4）実環境下において PMM の曲げ強度はポリマーの 被膜が支配的となり, 圧縮強度はセメントの水和が 支配的に関与していることが明らかとなった。

（5）P/C が高くなるに従い中性化に対する抵抗性は高 くなった。しかし, 初期の数時間だけ封縅養生した 場合や徐々に乾燥が進む条件では水分の移動が緩 慢となり，移動できるポリマー量も少なく被膜は不 完全なものとなる可能性が考えられる。このことな どから有効な対策としては 2 日以上のシートなどに よる封縅養生の実施が必要であると考えられる。

（6）実環境下において断面修復材にポリマーを添加す ることは，母材コンクリートとの境界面で発生する ひび割れを極力抑制できると考えられる。

（7）PMM に混入した収縮低減剤と膨張材は, 作用機 構が異なることから両者を併用することはひび割 れ抑制に対して相乗効果を発揮し, 有効な対策方法 であると考えられる。

\section{7. おわりに}

実環境下において断面修復材にポリマーを添加するこ とは物質遮断性や寸法安定性の確保に有効であることが 明らかとなった。また，PMM を使用する場合には初期 の水分の蒸発を極力抑制しセメントの水和を促すことが 最も有効であると考えられる。しかし，この詨策がとれ ない状況で，なるべく長く，少なくとも 2 日以上のシー 卜などによる封縅養生が有効な養生方法であると考えら れる。また，高 $\mathrm{P} / \mathrm{C}$ の膜養生剂を散布することや，収縮 補償材料を適切に添加することが而久性確保の観点から 有効な対策であると考えられる。

以上より，実環境下において PMM を使用する場合に は充分にその性能を理解することが重要であり，また，
対象構造物の置かれた環境に配慮し，養生などの施工方 法を決定する必要があると考えられる。

なお，本報において実環境下における PMM 表面部で のポリマーの被膜過程を水分の移動現象とともに予測し た。さらに，この概念を使って初期の養生条件の違いに よる中性化抵抗性に関する考察などを行った。今後，予 測した概念の裏づけを行うため, 水分蒸発(消費)に伴う ポリマーの移動速度と被膜過程, さらには PMM 中のセ メントの水和反応程度などについてさらに検討していく 予定である。

謝辞: 本研究は, 東京大学生産技術研究所で行ったもの であり，岸利治准教授，加藤佳孝准教授をはじめ，研究 室の皆様に多大な協力を頂きました。ここに記して謝意 を表します。

\section{参 考 文 献}

1）廣田良輔，鳥取誠一，宮本征夫，稲葉紀昭，朝倉俊弘：鉄道土木構 造物の耐久性, 山海堂, 2002.8

2）石橋忠良: 鉄道施設の点検, 調査, 診断, コンクリート工学, Vol.42, No.5, pp.42-46, 2004.5

3) M.U.K.Afridi, Y.Ohama, M.Zafarlqbal, et al. : Behavior of $\mathrm{Ca}(\mathrm{OH})_{2}$ in polymer modified mortars, The international Journal of Cement Composites and Lightweight Concrete, Volume.11, Number4, 1989

4）堀田智明, 名和豊春 : セメント系材料の自己収縮に関する研究, 共 和技報 No.517, pp.3941-3948，2001

5）名和豊春, 出雲健司, 矢野めぐみ, 湯浅昇：モルタル硬化体中の湿 度変化と自己収縮の関係, Cement Science and Concrete Technology, No.55, pp.218-224, 2001

6）上田政文：湿度と蒸発，コロナ社，2000.2

7) S.Chandra, Y.Ohama: POLYMERS in CONCRETE, CRCpress, 1994

8) A.Beeldens, J.Monteny, E.Vincke, et al. : Resistance to biogenic sulphuric acid corrosion of polymer-modified mortars, Cement \& Concrete Composites , VOL.23, pp.47-56, 2001

9）林 志翔:低水セメント比ポリマーセメントモルタルの高流動化お よび高強度化のメカニズム，コンクリート工学論文集，VOL.17, No.1, pp.41-50, 2006

10）セメント協会：セメント硬化体研究委員会報告書，2001.5

11）青木 茂, 三浦律彦, 三浦 尚 : 高強度連壁コンクリートの非排水 三軸加圧下における強度性状, 土木学会論文集, No.571, V-36, pp.105-117, 1997

12）羽原俊祐: 硬化コンクリートの組織及び空隙構造と物性の関係に関 する研究, 慶応大学学位論文

13）盛岡 実, 荻原宏俊, 坂井悦郎, 大門正機 : 膨張材を混和したセメ ントペーストの化学収縮と自己体積変化, コンクリート工学年次論 文報告集，VOL.21，No.2，pp.157-162，1999

14）盛岡実，萩原宏俊，酒井悦郎，大門正機 : 膨張材の水和反応と材料 設計，セメント・コンクリート論文集，Vol.54，pp.111-116，2000

15）永松静也, 佐藤嘉司, 真鍋宏司 : セメント硬化体の乾燥収縮理論と 乾燥収縮低減剂の効果について, 日本建築学会大会学術講演梗概集, pp.485-486, 1984.10

16）関西ペイント技術研究所: 水性塗料の技術動向, 日本塗料新聞社, 1994.4 
18）大濱嘉彦，出村克宣：ポリマーセメントコンクリート/ポリマーコ

Study on Performance Evaluation of Polymer-Modified Mortar under Real Environment

By Masanori Ito and Taketo Uomoto

\section{Concrete Research and Technology, Vol.19, No.3, Sep.2008}

Synopsis: PMM has been widely used because of its high durability performance though it is relatively expensive. Unfortunately, many early re-deteriorated cases have been observed just a short time after the first repair. The re-deterioration is due to the fact that important factors like deteriorated grasp, time, material of repair, environmental influence etc., are not considered carefully for the repair work. Among those factors, the environmental impact has been hardly examined up to now. Therefore, the purpose of this research was to quantitatively evaluate the environmental impact on the performance of patching repair material. In the experiment, the material and mix design of PMM were varied widely. The environmental conditions were: Seal, Dry and Windy, Low-temp and High-temp conditions. Evaluation techniques were elucidation of cement hydration and film process of polymer in PMM. This study examined the influence of above factors on strength and durability of PMM. And, the stiffening model of PMM was constructed based on quantitative experimental results.

Keywords: Polymer-modified mortar, Film, Hydration, Micro pore, Stiffening model, Shrinkage compensation materials 